\title{
Correction to: Changes in ocular surface and Meibomian gland after penetrating Keratoplasty
}

Kang Yoon Kim", Byunghoon Chung ${ }^{2}$, Eung Kweon Kim ${ }^{3,4}$, Kyoung Yul Seo ${ }^{1}$, Ikhyun Jun ${ }^{1 *}$ and Tae-im Kim ${ }^{1, *^{*}}$

\section{Correction to: BMC Ophthalmol 21, 85 (2021) \\ https://doi.org/10.1186/s12886-021-01851-4}

Following publication of the original article [1], we were notified that Ikhyun Jun should have also been marked as a corresponding author.

The original article has been corrected.

\author{
Author details \\ 'Department of Ophthalmology, Institute of Vision Research, Yonsei \\ University College of Medicine, Seoul, Republic of Korea. ${ }^{2}$ Department of \\ Ophthalmology, International St. Mary's Hospital, Catholic Kwandong \\ University College of Medicine, Incheon, Republic of Korea. ${ }^{3}$ Saevit Eye \\ Hospital, Goyang, Republic of Korea. ${ }^{4}$ Department of Ophthalmology, \\ Corneal Dystrophy Research Institute, Yonsei University, College of Medicine, \\ Seoul, Republic of Korea.
}

Published online: 05 March 2021

\section{Reference}

1. Kim KY, et al. Changes in ocular surface and Meibomian gland after

penetrating Keratoplasty. BMC Ophthalmol. 2021;21:85. https://doi.org/10.11 86/s1 2886-021-01851-4.

The original article can be found online at https://doi.org/10.1186/s12886021-01851-4

* Correspondence: hadesdual@yuhs.ac; tikim@yuhs.ac

'Department of Ophthalmology, Institute of Vision Research, Yonsei University College of Medicine, Seoul, Republic of Korea

Full list of author information is available at the end of the article

(c) The Author(s). 2021 Open Access This article is licensed under a Creative Commons Attribution 4.0 International License, which permits use, sharing, adaptation, distribution and reproduction in any medium or format, as long as you give appropriate credit to the original author(s) and the source, provide a link to the Creative Commons licence, and indicate if changes were made. The images or other third party material in this article are included in the article's Creative Commons licence, unless indicated otherwise in a credit line to the material. If material is not included in the article's Creative Commons licence and your intended use is not permitted by statutory regulation or exceeds the permitted use, you will need to obtain permission directly from the copyright holder. To view a copy of this licence, visit http://creativecommons.org/licenses/by/4.0/ The Creative Commons Public Domain Dedication waiver (http://creativecommons.org/publicdomain/zero/1.0/) applies to the data made available in this article, unless otherwise stated in a credit line to the data. 